\title{
Variasi Tingkah Laku Reproduksi Rusa Sambar pada Manajemen Pemeliharaan Intensif di Habitat Ex Situ
}

\author{
The Description of Intensively Captived Sambar Deer's Reproductive Behavior
}

\author{
Heri Dwi Putranto1,2 \\ ${ }^{1}$ Jurusan Peternakan Fakultas Pertanian Universitas Bengkulu \\ ${ }^{2}$ Program Pascasarjana Pengelolaan Sumberdaya Alam dan Lingkungan, \\ Fakultas Pertanian Universitas Bengkulu \\ Jalan Raya W.R. Supratman, Kandang Limun, Bengkulu \\ 38371A Telp +62-736-21170 ext.219 Fax +62-736-21290
}

\begin{abstract}
Sambar deer (Cervus unicolor) has a potency to be developed as a protein resource, however its reproductive behavior (doe estrus manifestations and buck mating behavior) is still unclear. The objective of this study was to monitor the effect of intensively management system on reproductive behaviors and to identify the seasonal effect on reproductive behaviors of Sambar deer. A pair of six years of age Sumatran sambar deer was used in this study. Daily observation of visual estrus manifestations of doe and visual mating behaviors of buck were conducted using focal-animal sampling by two animal keepers for 9 hours during May-October 2009. There was a significant effect of season on doe visual estrus manifestations and buck mating behaviors $(\mathrm{p}<0.01)$. Doe visual estrus manifestations include apparent reddening and swelling of the external genitalia, loss of appetite and a natural tendency of the doe to approach the buck. Buck mating behaviors include vocalization, aggressiveness, chasing the doe, doe genitalia kissing, buck mount the doe, penile erection, flehmen, intromition and copulation. It is possible to identify the seasonal effect on reproductive behaviors of Sambar deer, and there were 3 doe visual estrus manifestations and 10 buck mating behaviors.
\end{abstract}

Key words: Intensive management, Reproductive behaviors, Sambar deer, Season.

\begin{abstract}
ABSTRAK
Rusa Sambar (Cervus unicolor) merupakan ruminansia yang berpotensi sebagai sumber protein hewani dan layak dikembangkan, deskripsi tingkah laku reproduksinya (tingkah laku estrus betina dan tingkah laku kawin jantan) sampai kini belum banyak diketahui. Penelitian dirancang untuk merekam variasi tingkah laku reproduksi dominan rusa Sambar yang mendapat perlakuan pemeliharaan secara intensif dan untuk mengetahui pengaruh musim (hujan dan kemarau) terhadap tingkah laku reproduksinya. Sepasang rusa Sambar berumur enam tahun yang dipelihara pada CZAL Jurusan Peternakan Faperta Unib diobservasi secara visual dan dicatat tingkah laku reproduksinya selama Mei - Oktober 2009. Hasil analisa uji $t$-student, musim berpengaruh sangat nyata terhadap tiga macam variasi tingkah laku estrus dominan betina yaitu aktifitas menjilat jantan, aktifitas menunggangi jantan atau individu lain dan berkurangnya nafsu makan $(\mathrm{p}<0,01)$. Selanjutnya, musim juga berpengaruh sangat nyata terhadap sembilan macam variasi tingkah laku kawin jantan antara lain vokalisasi, agresif, aktifitas menjilat betina, aktifitas mencium genitalia betina, aktifitas menunggangi betina, ereksi penis, flehmen, aktifitas menggosokkan tubuh ke betina serta mengikuti betina $(\mathrm{p}<0,01)$, kecuali aktifitas intromisi dan kopulasi. Dapat disimpulkan bahwa faktor musim mempengaruhi frekuensi tingkah laku reproduksi dan tercatat tiga macam variasi tingkah laku reproduksi dominan betina dan sepuluh macam tingkah laku reproduksi dominan jantan.
\end{abstract}

Kata kunci: Musim, pemeliharaan intensif, rusa Sambar, tingkah laku reproduksi. 


\section{PENDAHULUAN}

Rusa Sambar (Cervus unicolor Equinus) adalah salah satu dari empat jenis rusa di Indonesia yang sudah dilindungi oleh undang-undang namun jumlah populasinya terus berkurang akibat perburuan liar dan semakin tingginya degradasi habitat aslinya (Putranto et al., 2011). Berdasarkan daftar merah (The Red List of Threatened Species) yang dikeluarkan IUCN tahun 2007, rusa Sambar berstatus Lower Risk/Least Concern dan termasuk dalam spesies yang dilindungi oleh pemerintah Indonesia.

Menurut Putranto et al. (2010), rusa Sambar merupakan salah satu mamalia endemik yang cukup penting di kawasan Taman Nasional Kerinci Seblat (TNKS) yang $22,73 \%$ areal teritorialnya berada di wilayah Provinsi Bengkulu dimana populasinya terus menyusut, dibuktikan dengan sulit ditemukannya pada habitat in situ. Penurunan populasi tanpa disertai upaya konservasi, akan menempatkan ruminansia endemik Bengkulu ini dalam status terancam punah suatu saat nanti.

Upaya domestikasi rusa Sambar di Indonesia khususnya Provinsi Bengkulu belum populer, sehingga sistem manajemen domestikasi ruminansia ini belum jelas. Pemeliharaan ruminansia ini di kota Bengkulu hanya bertujuan untuk koleksi dan bersifat non komersil (Imelda, 2004). Padahal rusa Sambar berpotensi didomestikasikan untuk tujuan konservasi, sebagai sumberdaya alam baru untuk pemenuhan kebutuhan komersial dan rekreatif serta menjadi alternatif sumber protein hewani masyarakat. Keunggulan lain dari rusa Sambar adalah mampu beradaptasi pada berbagai habitat, efisien dalam penggunaan pakan untuk diubah menjadi daging, tahan terhadap penyakit, dagingnya memiliki kandungan lemak dan kalori yang rendah sehingga cocok dikonsumsi oleh orang yang diet kolesterol.

Informasi fisiologi reproduksi merupakan data fundamental sebelum upaya konservasi dilanjutkan dengan teknologi reproduksi lanjut (Putranto et al., 2007a, b, c). Penelitian ini merupakan penelitian awal yang spesifik membahas tentang status dan deskripsi fisiologi reproduksi rusa Sambar endemik Bengkulu. Adapun tujuan dari penelitian ini adalah untuk memberikan gambaran berupa variasi tingkah laku reproduksi dominan rusa Sambar yang mendapatkan perlakuan dipelihara pada sistem manajemen intensif melalui observasi visual dan pencatatan aktifitas seksualnya dan untuk mengetahui pengaruh musim terhadap tingkah laku reproduksi. Hipotesis penelitian ini adalah musim (musim hujan dan kemarau) serta perlakuan pemeliharaan intensif dimana kebutuhan makanan dan minum rusa Sambar disediakan secara cut and carry system akan mempengaruhi variasi dan frekuensi tingkah laku reproduksi rusa Sambar pada habitat ex situ.

\section{MATERI DAN METODE}

Kegiatan penelitian telah dimulai tanggal 1 April 2009 dan berakhir pada tanggal 31 Oktober 2009. Penelitian ini dirancang sebagai upaya domestikasi rusa Sambar dengan membuat habitat buatan (artificial environment) secara permanen berupa kandang isolasi (isolation room) dan lapangan terbuka (open barn). Kandang isolasi seluas $2 \times 3 \mathrm{~m}^{2}$ dan lapangan terbuka (open barn) seluas $5 \times 5$ $\mathrm{m}^{2}$ dibangun di lahan kandang rusa milik Jurusan Peternakan, Fakultas Pertanian, Universitas Bengkulu yang berlokasi di Commercial Zone and Animal Laboratory (CZAL). Objek penelitian diberikan akses bebas terhadap pakan, air minum, sinar matahari dan aktifitas sosialisasi di lapangan terbuka selama siang hari ( 9 jam per hari). Pada malam hari, rusa digiring masuk ke dalam kandang isolasi.

Pada penelitian ini digunakan seekor rusa Sambar betina yang diidentifikasikan dengan nama Mimi (오, 5 tahun). Rusa tersebut telah matang kelamin, dan berdasarkan recording (catatan) Mimi berstatus primipara. Saat penelitian dimulai, Mimi dikondisikan untuk non-pregnant dan non-lactating.

Peneliti dan petugas kandang dilengkapi dengan alat tulis, tabel skor tingkah laku reproduksi, kamera digital merk Casio Exilim seri EX-Z30 spesifikasi 
3.2 mega pixels, 3x optimum zoom (Casio Computer, China) untuk merekam temuan selama penelitian, timbangan ternak digital (Allflex FX-1) untuk menimbang ternak dengan nilai akurasi hingga $0.1 \mathrm{~kg}$, analitic balance untuk neraca timbang serta fasilitas kandang lainnya seperti tempat pakan individu, tempat minum individu, selang air sepanjang 40 $\mathrm{m}$, sapu lidi untuk membersihkan kandang dan lain sebagainya. Bahan yang dipergunakan antara lain rumput lapangan, legum serta dedak padi sebagai pakan rusa Sambar dengan jumlah dan komposisi $12: 2: 3$ setiap hari dan air minum ad libitum, serta suplementasi garam mineral $\mathrm{NaCl}$ dan obat cacing Overm.

Pengamatan atau observasi visual terhadap parameter tingkah laku reproduksi rusa Sambar dilakukan di siang hari selama 9 jam per hari (pukul 08:00 hingga 17:00) oleh dua orang peneliti atau petugas kandang setiap hari. Pengamatan dilakukan dari jarak 15 meter dari kandang sehingga diasumsikan kehadiran peneliti dan petugas kandang tidak mengganggu aktifitas rusa serta meminimalkan munculnya cekaman lingkungan (stres) terhadap objek penelitian. Parameter tingkah laku reproduksi dibagi menjadi 2 yaitu tingkah laku estrus pada rusa Sambar betina dan tingkah laku kawin pada rusa Sambar jantan. Setiap variasi tingkah laku reproduksi atau aktifitas seksual yang terlihat dicatat dan dihitung rerata frekuensinya dalam 30 hari (1 bulan).

Data tingkah laku reproduksi selama periode observasi ditampilkan dalam bentuk tabel dilengkapi dengan mean \pm standar eror mean (SEM) dan dibahas secara deskriptif. Untuk membedakan pengaruh musim terhadap parameter dilakukan analisa statistik uji $t$-student. Seluruh analisa data menggunakan program Windows Software Microsoft Office Excell 2003 dan software SSRI Excell 2002.

\section{HASIL DAN PEMBAHASAN}

Rusa Sambar memiliki potensi untuk dikembangkan sebagai ternak ruminansia penghasil daging atau ternak potong. $\mathrm{Di}$ Indonesia, tempat penangkaran rusa Sambar yang sudah berhasil mengembangkan potensi produksi dan reproduksi rusa Sambar berada di propinsi Kalimantan Timur (Muchsinin et al., 2002).

\section{Klimatologi Lokasi Penelitian \\ Secara umum di Indonesia, periode bulan Agustus hingga Maret} diklasifikasikan sebagai musim hujan dan periode bulan April hingga Juli diklasifikasikan sebagai musim kemarau (Anonimous, 2009). Ditambahkan oleh Soetrisno et al. (2009) bahwa periode bulan Mei hingga Juli 2009 diasumsikan sebagai representasi dari musim kemarau dan periode bulan Agustus hingga Oktober 2009 diasumsikan sebagai representasi dari musim hujan.

Menurut hasil rekaman Stasiun Klimatologi KL II Pulau Baai Bengkulu tahun 2009, selama kurun waktu bulan Mei hingga Oktober 2009 suhu rata-rata

Tabel 1. Frekuensi tingkah laku estrus rusa betina

\begin{tabular}{lccc}
\hline \multirow{2}{*}{ Bulan } & \multicolumn{2}{c}{ Frekuensi Tingkah Laku Estrusa) } \\
\cline { 2 - 4 } & Menjilat Jantan & $\begin{array}{c}\text { Menunggangi Jantan atau } \\
\text { Individu Lain }\end{array}$ & Hilang Nafsu Makan b) \\
\hline Mei & 0 & 0 & 2 \\
Juni & 0 & 3 & 4 \\
Juli & 2 & 10 & 0 \\
Agustus & 0 & 0 & 0 \\
September & 0 & 0 & 0 \\
Oktober & 0 & 0 & 1,83 \\
\hline Rerata & 0,33 & 2,17 & \\
\hline Keterangan: & a) Nilai frekuensi dihitung dalam satuan kali per bulan (n/bulan) \\
\hline
\end{tabular}


Tabel 2. Rerata frekuensi tingkah laku estrus betina selama musim kemarau dan musim hujan

\begin{tabular}{|c|c|c|c|}
\hline \multirow[b]{2}{*}{ Musim } & \multicolumn{3}{|c|}{ Frekuensi Tingkah Laku Estrus ${ }^{a)}$} \\
\hline & Menjilat Jantan & $\begin{array}{c}\text { Menunggangi Jantan atau } \\
\text { Individu Lain } \\
\end{array}$ & Hilang Nafsu Makan b) \\
\hline Kemarau & $0,7 a$ & $4,3 \mathrm{a}$ & 3,7 a \\
\hline Hujan & $0^{b}$ & $0^{b}$ & $0^{b}$ \\
\hline
\end{tabular}

Keterangan: a) Nilai frekuensi dihitung dalam satuan kali per bulan (n/bulan), b) Nilai frekuensi dihitung dalam satuan hari/bulan, superskrip yang berbeda pada kolom vertikal yang sama menunjukkan berbeda sangat nyata pada taraf $\mathrm{p}<0,01$ pada saat dianalisa menggunakan uji $t$-student.

kota Bengkulu adalah $26,5^{\circ} \mathrm{C}$ (kisaran 26,1 $-26,8^{\circ} \mathrm{C}$ ) dengan suhu tertinggi berada di bulan Mei $2009\left(26,8^{\circ} \mathrm{C}\right)$. Selanjutnya, untuk kurun waktu bulan Mei hingga Oktober 2009 curah hujan rata-rata kota Bengkulu adalah 189,6 mm/bulan. Ratarata curah hujan selama musim kemarau (Mei-Juli 2009) adalah $86,3 \mathrm{~mm} /$ bulan dan musim hujan (Agustus-Oktober 2009) adalah 194,5 mm/bulan. Selama kurun waktu bulan Mei hingga Oktober 2009 kelembaban nisbi rata-rata kota Bengkulu adalah $84 \%$ /bulan. Rata-rata kelembaban nisbi selama musim kemarau (Mei-Juli 2009) adalah 85,3\%/bulan dan musim hujan (Agustus-Oktober 2009) adalah $82 \% /$ bulan.

\section{Tingkah Laku Estrus Betina}

Berdasarkan pengamatan visual selama penelitian, rusa Sambar betina memperlihatkan beberapa tingkah laku estrus antara lain aktifitas menjilat rusa jantan, aktifitas menunggangi rusa jantan atau individu lain dan hilang/berkurangnya nafsu makan (Tabel 1). Hasil analisa statistik uji $t$-student pada parameter tingkah laku estrus betina menunjukkan bahwa musim (musim kemarau dan musim hujan) berpengaruh sangat nyata terhadap tingkah laku estrus rusa betina ( $<<0,01$; Tabel 2$)$.

Tingkah laku estrus yang paling tinggi frekuensinya adalah menunggangi jantan atau individu lainnya $(2,17 \pm 1,1$ kali/bulan), diikuti dengan hilangnya nafsu makan $(1,83 \pm 0,7$ hari/bulan dan aktifitas menjilat pejantan $(0,33 \pm 0,8$ kali/bulan). Analisis lanjut juga menunjukkan bahwa musim sangat berperan dalam mengatur frekuensi tingkah laku estrus rusa betina. Tetapi mekanismenya belum bisa diketahui.

Rusa Sambar betina secara signifikan hilang/berkurang nafsu makannya selama musim kemarau dibanding selama musim hujan $(\mathrm{p}<0,01)$. Data klimatologi menunjukkan bahwa rerata temperatur udara dan kelembaban nisbi kota Bengkulu selama musim kemarau tahun 2009 lebih tinggi daripada musim hujan tahun 2009. Kondisi kelembaban tinggi dan cuaca yang panas diperkirakan memberikan kontribusi penyebab terjadinya hilang/berkurangnya nafsu makan rusa Sambar betina. Seperti diketahui bahwa selama cekaman panas, secara fisiologis tubuh akan mengurangi intake pakan dan meningkatkan intake air minum.

Tabel 3. Frekuensi tingkah laku kawin rusa jantan

\begin{tabular}{lcccccccccc}
\hline \multirow{2}{*}{ Bulan } & \multicolumn{10}{c}{ Frekuensi Tingkah Laku Kawin ${ }^{2)}$} \\
\cline { 2 - 10 } & A & B & C & D & E & F & G & H & I \\
\hline Mei & 0 & 7 & 6 & 22 & 0 & 0 & 0 & 0 & 0 \\
Juni & 0 & 9 & 5 & 24 & 0 & 0 & 2 & 0 & 0 \\
Juli & 3 & 13 & 16 & 52 & 0 & 0 & 2 & 0 & 0 & 0 \\
Agust & 1 & 48 & 32 & 91 & 0 & 0 & 0 & 7 & 12 & 43 \\
Sept & 13 & 44 & 39 & 61 & 4 & 8 & 4 & 26 & 0 & 36 \\
Okt & 0 & 21 & 0 & 11 & 0 & 0 & 0 & 0 & 3 \\
\hline Rerata & 2,8 & 23,7 & 16,3 & 43,5 & 0,7 & 1,3 & 1,3 & 5,5 & 2,5 \\
\hline
\end{tabular}

Keterangan: a) Nilai frekuensi dihitung dalam satuan kali per bulan (n/bulan)

A: vokalisasi, B: bersifat agresif, C: menjilati betina, D: mencium genitalia betina, E: menunggangi betina, F: ereksi penis, G: intromisi dan kopulasi, $\mathrm{H}$ : flehmen, I: menggosokkkan tubuh ke betina, J: mengikuti betina. 
Tabel 4. Rerata frekuensi tingkah laku kawin jantan selama musim kering dan musim hujan

\begin{tabular}{lcccccccccc}
\hline \multirow{2}{*}{ Bulan } & \multicolumn{10}{c}{ Frekuensi Tingkah Laku Kawin ${ }^{\mathrm{a})}$} \\
\cline { 2 - 11 } & $\mathrm{A}$ & $\mathrm{B}$ & $\mathrm{C}$ & $\mathrm{D}$ & $\mathrm{E}$ & $\mathrm{F}$ & $\mathrm{G}$ & $\mathrm{H}$ & $\mathrm{I}$ & $\mathrm{J}$ \\
\hline Kemarau & $1,0^{\mathrm{a}}$ & $9,7^{\mathrm{a}}$ & $9,0^{\mathrm{a}}$ & $32,7^{\mathrm{a}}$ & $0,0^{\mathrm{a}}$ & $0,0^{\mathrm{a}}$ & $1,3^{\mathrm{a}}$ & $0,0^{\mathrm{a}}$ & $0,0^{\mathrm{a}}$ & $0,0^{\mathrm{a}}$ \\
Hujan & $4,7^{\mathrm{b}}$ & $37,7^{\mathrm{b}}$ & $23,7^{\mathrm{b}}$ & $54,3^{\mathrm{b}}$ & $1,3^{\mathrm{b}}$ & $2,7^{\mathrm{b}}$ & $1,3^{\mathrm{a}}$ & $11,0^{\mathrm{b}}$ & $5,0^{\mathrm{b}}$ & 88,0
\end{tabular}

Keterangan: a) Nilai frekuensi dihitung dalam satuan kali per bulan (n/bulan), superskrip yang berbeda pada kolom vertikal yang sama menunjukkan berbeda sangat nyata pada taraf $p<0,01$ pada saat dianalisa menggunakan uji $t$-student, A: vokalisasi, B: bersifat agresif, C: menjilati betina, D: mencium genitalia betina, E: menunggangi betina, F: ereksi penis, G: intromisi dan kopulasi, H: flehmen, I: menggosokkkan tubuh ke betina, J: mengikuti betina

Rusa merupakan hewan polyestrus dan dikawasan tropis dapat melakukan aktifitas seksual (kawin) sepanjang waktu dalam 1 tahun (Semiadi et al., 2005; Craven dan Hygnstorm, 1994). Hasil penelitian juga memperlihatkan fakta yang sama, dibuktikan oleh durasi estrus rusa betina(1 hingga 3 hari) yang selalu muncul baik di musim kemarau maupun musim hujan (Putranto et al., 2010).

\section{Tingkah Laku Kawin Jantan}

Berdasarkan pengamatan visual selama penelitian, rusa Sambar jantan memperlihatkan 10 macam tingkah laku kawin antara lain vokalisasi, bersifat agresif, menjilat betina, mencium genitalia betina, menunggangi betina, ereksi penis, intromisi dan kopulasi, flehmen, menggosokkan tubuh ke betina serta mengikuti betina (Tabel 3).

Hasil analisa statistik uji $t$-student pada parameter tingkah laku kawin rusa jantan menunjukkan bahwa musim (musim kemarau dan musim hujan) berpengaruh sangat nyata terhadap tingkah laku kawin rusa Sambar jantan, kecuali pada aktifitas intromisi dan kopulasi ( $p<0,01$; Tabel 4).

Tingkah laku kawin yang paling tinggi frekuensinya adalah mencium genitalia betina $(43,5 \pm 12,3 \mathrm{kali} / \mathrm{bulan})$, diikuti dengan bersifat agresif $(23,7 \pm 7,3$ kali/bulan) dan aktifitas menjilat betina $(16,3 \pm 6,5 \mathrm{kali} / \mathrm{bulan})$. Analisis lanjut juga menunjukkan bahwa musim sangat berperan dalam mengatur frekuensi tingkah laku kawin rusa jantan, kecuali pada tingkah laku intromisi dan kopulasi. Hal tersebut terlihat dari data bahwa seluruh tingkah laku kawin jantan lebih tinggi frekuensinya pada saat musim hujan dibanding musim kemarau (Tabel 4).

Menurut Putranto et al. (2007a), pada hewan mamalia tingkah laku berupa vokalisasi dan flehmen merupakan tingkah laku kawin yang paling mudah dideteksi. Tingkah laku kawin jantan ini selama musim hujan diduga lebih menstimulasi libido jantan seperti terlihat dari tingginya tingkah laku bersifat agresif. Menurut Craven dan Hygnstorm (1994), agresivitas rusa jantan akan meningkat pada saat musim kawin rusa. Lebih jauh, dari hasil penelitian terlihat bahwa aktifitas kawin/seksual rusa jantan terlihat aktif selama musim hujan. Ini dilihat dari frekuensi menunggangi betina, ereksi penis dan intromisi, serta diakhiri dengan kopulasi. Aktifitas kawin utama tersebut tampak muncul di bulan September.

\section{SIMPULAN}

Hasil pengamatan di lapangan menunjukkan bahwa musim kemarau dan musim hujan berpengaruh sangat nyata terhadap parameter tingkah laku reproduksi rusa Sambar endemik Bengkulu yaitu tingkah laku estrus betina dan tingkah laku kawin jantan. Terdapat tiga macam variasi tingkah laku dominan estrus rusa betina antara lain menjilat tubuh jantan, menunggangi jantan atau individu lain dan hilang/berkurangnya nafsu makan. Peneliti mencatat sebanyak 10 macam variasi tingkah laku kawin jantan antara lain vokalisasi, bersifat agresif, menjilat betina, mencium genitalia betina, menunggangi betina, ereksi penis, flehmen, menggosokkan tubuh ke betina 
serta mengikuti betina, intromisi dan kopulasi.

\section{UCAPAN TERIMA KASIH}

Penulis mengucapkan terima kasih kepada Direktorat Jenderal Pendidikan Tinggi Kementrian Pendidikan Nasional Republik Indonesia yang telah membiayai penelitian ini melalui Hibah Penelitian Fundamental tahun 2009 melalui surat perjanjian nomor: 5006/94/J30.2/PG/2009. Ucapan terima kasih juga ditujukan kepada seluruh tim peneliti Ir. Edi Soetrisno, M.Sc., Nurmeiliasari, S.Pt., M.Sc., Ahmad Zueni, S.Pt, M.Si dan Berry Gibson, S.Pt, M.Si yang telah meluangkan banyak waktu dalam membantu recording data penelitian di lapangan.

\section{DAFTAR PUSTAKA}

Anonimous. 2009. Bengkulu Weather Forecast. Bengkulu, Indonesia: Badan Meteorologi Klimatologi dan Geofisika: 1-15 (in Indonesian).

Craven, S.R., S.E. Hygnstrom. 1994. Deer. In: Prevention and Control of Wildlife Damage. USA: USDA: 2540.

Imelda. 2004. Tingkah Laku Sosial Rusa Sambar (Cervus unicolor Equinus) di Balai Raya Semarak Bengkulu. Skripsi. Jurusan Peternakan Fakultas Pertanian Universitas Bengkulu (tidak dipublikasikan).

Muchsinin, M., G. Semiadi, A. Dradjat, W.R. Farida. 2002. Developing sambar deer as new domesticated animal in East Kalimantan. In: Ungulate Bioecology and Conservation Seminar; Bogor, Indonesia. Proceeding: 61-68 (in Indonesian).

Putranto, H. D., E. Soetrisno, Nurmeiliasari, A. Zueni, B. Gibson. 2011. Recognition of seasonal effect on captive Sumatran sambar deer reproductive cyclicity and sexual behaviors. Biodiversitas 12 (2): 200203.

Putranto, H.D., E. Soetrisno, Nurmeiliasari. 2010. Estimasi siklus estrus dan pertambahan berat badan rusa sambar betina (Cervus unicolor Equinus) domestikasi. Proc.Semirata Bidang Ilmu Pertanian BKS-PTN Wilayah Barat tahun 2010: 954-959.

Putranto, H.D., S. Kusuda, K. Inagaki, G. Kumagai, R. Ishii-Tamura, Y. Uziie, O. Doi. 2007a. Ovarian activity and pregnancy in the Siberian tiger, Panthera tigris altaica, assessed by fecal gonadal steroid hormones analyses. J. Vet. Med. Sci. 69 (5): 569-571.

Putranto, H.D., S. Kusuda, H. Hashikawa, K. Kimura, H. Naito, O. Doi. 2007b. Fecal progestins and estrogens for endocrine monitoring of ovarian cycle and pregnancy in Sumatran orangutan (Pongo abelii). Jpn. J. Zoo. Wildl. Med. 12 (2): 97-103.

Putranto, H.D., S. Kusuda, T. Ito, M. Terada, K. Inagaki, O. Doi. 2007c. Reproductive cyclicity based on fecal steroid hormones and behaviors in Sumatran tigers, Panthera tigris sumatrae. Jpn. J. Zoo. Wild1. Med. 12 (2): 111-115.

Semiadi, G., I.G.M. Adhi, A. Trasodiharto. 2005. Calving pattern of captive sambar deer (Cervus unicolor) in East Kalimantan. Biodiversitas 6 (1): 5962.

Soetrisno, E., H.D. Putranto, dan Nurmeiliasari. 2009. Performans Fisiologi Reproduksi Ruminansia Endemik Bengkulu, Rusa Sambar (Cervus unicolor Equinus), Dan Potensi Domestikasinya. Laporan Penelitian Fundamental Tahun Ke-1. Lembaga Penelitian Universitas Bengkulu. 69 hal. 